\title{
Inovasi Pembelajaran Bagi Guru Sekolah Dasar Dalam Mendesain Video Pembelajaran
}

\author{
Marleny Leasa ${ }^{1}$, Fifi Astafiani Syam ${ }^{2}$, Muhammad Sayyadi ${ }^{3}$, John Rafafy Batlolona ${ }^{4}$ \\ ${ }^{1,2}$ Program Studi Pendidikan Guru Sekolah Dasar, Fakultas Keguruan dan Ilmu Pendidikan, \\ Universitas Pattimura \\ ${ }^{3}$ Program Studi Pendidikan Fisika, Fakultas Sains dan Teknologi, Universitas Kanjuruhan Malang \\ ${ }^{4}$ Program Pendidikan Profesi Guru, Fakultas Keguruan dan Ilmu Pendidikan, Universitas Pattimura \\ marlenyleasa3@gmail.com
}

\begin{abstract}
ABSTRAK
Guru masa depan wajib menguasai ICT dan menggunakannya untuk mengembangkan iklim pembelajaran konstruktivis. Salah satu bentuk penguasaan ICT adalah mengembangkan media pembelajaran dengan mengaplikasikan software tertentu. Permasalahan yang dialami Kelompok Kerja Guru Gugus 1 di Saparua yakni mereka mengalami kesulitan dan keterbatasan dalam merancang multimedia pembelajaran, sehingga pembelajaran belum memaksimalkan dan kurang menarik serta konvensional. Metode yang digunakan dalam pelatihan ini adalah ceramah dan workshop, yang melibatkan tim sebagai narasumber. Ceramah terkait dengan konten pelatihan berupa prinsip desain perangkat pembelajaran termasuk media pembelajaran. Konten dan prosedur ini dilakukan untuk mentransmisikan pengetahuan atau wawasan peserta, sebelum dilatih, sedangkan workshop bertujuan untuk melatih keterampilan peserta untuk membuat video pembelajaran. Hasil pretes dan posttes yang dicapai oleh peserta menunjukkan adanya peningkatan kemampuan peserta dalam mendesain perangkat pembelajaran dan media pembelajaran. Terkait dengan kemampuan mendesain perangkat pembelajaran, dari yang sebelumnya $90 \%$ menggunakan desain pembelajaran pada buku guru meningkat menjadi $80 \%$ kemampuan guru dalam mendesain perangkat pembelajaran mandiri yang relevan dan benar baik dalam menentukan tujuan instruktusional maupun metode serta model pembelajaran sesuai sintaknya. Selain itu, kemampuan mendesain media pembelajaran dari yang semula $80 \%$ menggunakan media visual dari buku atau charta serta $20 \%$ menggunakan media visual dari internet, meningkat menjadi $70 \%$ yang mendesain video pembelajaran dengan menggunakan sparkol videoscribe.
\end{abstract}

Kata kunci: literasi ICT, video pembelajaran, sparkol viodescribe

\begin{abstract}
Future teachers must master ICT and use it to develop a constructivist learning climate. One form of ICT mastery is developing learning media by applying certain software. The problems experienced by the Cluster 1 Teacher Working Group in Saparua is that they experience difficulties and limitations in designing multimedia learning, so learning has not yet maximized ICT-based learning media as a result of learning is less attractive and conventional. The method used in this training was lectures and workshops, which involved the team as a resource. Lectures was related to training content in the form of learning device design principles including learning media. The content and procedures were carried out to transmit participants' knowledge or insights before being trained, while the workshop aimed to train participants' skills in making learning videos. The results of the pretest and posttest achieved by participants showed an increase in the ability of participants to design learning tools and learning media. Related to the ability to design learning devices, the ability of teachers to design independent learning tools that are relevant and correct both in determining instructional goals as well as learning methods and models according to their syntax increased to $80 \%$. They previously $90 \%$ lean on using learning designs in teacher books. In addition, the ability to design instructional media from $80 \%$ using visual media from books or charters and $20 \%$ using visual media from the internet, increased to $70 \%$ who designed instructional videos using sparkol videoscribe.
\end{abstract}

Keywords: ICT literacy, learning videos, sparkol viodescribe. 


\section{PENDAHULUAN}

Pemerintah melalui Kemendikbud berupaya untuk meningkatkan kualitas pendidikan dalam rangka menghasilkan generasi emas yang unggul dan berkarakter. Salah satu upaya yang ditempuh adalah melakukan regulasi untuk meningkatan kompetensi guru berdasarkan pada Permendiknas No. 16 tahun 2007 tentang standar kompetensi guru dan kualitas lulusan. Peningkatan kompetensi guru diupayakan melalui peningkatan kompetensi profesional dan pedagogik, kegiatan pengembangan keprofesian berkelanjutan (PKB), dan kelompok kerja guru (KKG). Beberapa upaya yang ditempuh untuk memperbaiki kualitas pembelajaran antara lain, mempersiapkan guru dalam melaksanakan pembelajaran dan penilaian sesuai kompetensi dasar yang diamanatkan dan dibiasakan serta berorientasi HOTS, pembelajaran dan penilaian terintegrasi literasi yang menggunakan video pembelajaran, serta mempersiapkan pembelajaran berorientasi High Order Thingking Skills (HOTS) berupa transfer knowledge, critical and creative thinking, serta problem solving (Tawarah, 2017).

Pada era milenial saat ini, diharapkan pembelajaran harus berorientasi pada kemajuan teknologi dan perkembangan zaman. Jika tidak demikian, maka pembelajaran terkesan konvensional dan ketinggalan zaman. Oleh sebab itu, para pembelajar dituntut menguasai teknologi ICT dalam membelajarkan peserta didik, karena kompetensi tersebut merupakan inti dari seluruh kerangka kompetensi abad 21 yang diperlukan oleh pebelajar (Voogt \& Roblin, 2012). Pembelajaran kekinian tidak lagi berorientasi pada penguasaan pengetahuan dasar dan literasi yang terbatas, melainkan pada komponen utama pengetahuan yang disebut sebagai pengetahuan dasar, meta pengetahuan, dan pengetahuan humanistik. Pengetahuan dasar (foundational knowledge) mengisyaratkan pengetahuan apa saja yang diperlukan oleh siswa, termasuk di dalamnya pengetahuan konten inti, literasi digital, dan pengetahuan lintas disiplin ilmu. Pengetahuan meta diperlukan untuk bertindak di antaranya adalah kreativitas dan inovasi, pemecahan masalah dan berpikir kritis, serta komunikasi dan kolaborasi. Pengetahuan humanistik mendorong implementasi visi pebelajar pada konteks sosial dan global yang lebih luas. Pengetahuan ini mencakup pekerjaan, kepemimpinan, kompetensi budaya, dan kesadaran etis. Literasi digital dan informasi disebut sebagai salah satu kunci utama penentu kesuksesan seseorang di abad ini. Kompetensi ini diperlukan untuk mencari, mengatur, dan memproses informasi dari berbagai media melalui penggunaan media ICT yang bertanggung jawab dan beretika (Mishra \& Mehta, 2017). Dengan demikian, guru diharapkan menguasai teknologi ICT sehingga mampu membekali siswa dengan pengetahuan akan literasi informasi dan digital.

Kegiatan belajar yang baik sangat bergantung pada kehadiran teknologi, meskipun tidak seluruhnya seperti demikian. Keterampilan guru untuk mengadaptasi teknologi semacam itu untuk pembelajaran siswa adalah suatu keharusan. Dalam pendidikan modern, para guru tampaknya berupaya menghadirkan teknologi dalam kelas (Hasse, 2017). Pemanfaatan ICT dalam pembelajaran merupakan sarana untuk mengoperasian serta mengimplementasikan praktek pembelajaran, sehingga mampu mendorong lingkungan pembelajaran konstruktivis yang efektif (Orlando, 2013). Dampak lain pada pebelajar adalah memberikan peluang untuk memenuhi kebutuhan pendidikan sebagai masyarakat pengetahuan, terutama dalam mendorong pemikiran kritis, pemecahan masalah, dan keterampilan tingkat tinggi lainnya (Drent \& Meelissen, 2008).

Penguasaan kompetensi ICT dapat digunakan untuk mendesain video pembelajaran. Video juga telah banyak digunakan untuk menghasilkan konten belajar mandiri, yang paling sering didistribusikan melalui Internet. Video sebagai salah satu media pembelajaran digunakan untuk mempromosikan pembelajaran yang lebih mendalam dan bermakna (Mitra, Lewin-Jones, Barrett, \& Williamson, 2010). Video memiliki gambar visual yang dapat dilengkapi dengan informasi verbal untuk memperjelas maksud gambar tersebut (Sherin \& Han, 2004). Dalam penggunaannya video dirancang relevan dengan tingkat perkembangan kognitif siswa, sehingga tidak menimbulkan beban kognitif yang berlebihan dalam belajar yang kemudian dapat berdampak pada pemahaman, serta asimilasi organisasi pengetahuan. Video dapat digunakan untuk memperkuat pengetahuan karena memungkinkan siswa untuk menghubungkan gambar dari materi video ke situasi lain yang real dalam kehidupan seharihari. Selain itu, video dianggap memiliki kontribusi intelektual yang dapat membantu 
meningkatkan kemampuan pebelajar untuk retensi materi serta membangkitkan motivasi belajar. Video mudah diakses dan digunakan dalam modul multimedia interaktif (Ellis \& Childs, 1999).

Berdasarkan hasil survei yang dilakukan oleh tim pada Mitra yakni KKG Gugus 1 Kecamatan Saparua Kabupaten Maluku Tengah ditemukan beberapa informasi penting terkait dengan kompetensi guru dalam pembelajaran. Informasi yang paling urgensi adalah bahwa $90 \%$ guru menggunakan buku guru sebagai buku sumber utama dalam mengembangkan perangkat pembelajaran. Hal ini menunjukkan bahwa guru kurang kreatif untuk mendesain perangkat pembelajaran sendiri berdasarkan kebutuhan dan karakteristik siswa di kelasnya masing-masing. Makna lain yang diperoleh dari informasi tersebut adalah, sebagian guru sudah pasti merumuskan tujuan, metode, kegiatan pembelajaran, serta media pembelajaran dengan berpatokan pada informasi yang ada pada buku guru tersebut. Itu sebabnya, media pembelajaran yang digunakan oleh guru $80 \%$ bersumber pada media visual berupa gambar yang tertera pada buku guru serta charta yang ada di sekolah. Hanya 20\% guru yang terbiasa mencari berbagai media pembelajaran lain misalnya video dari youtube atau gambar serta animasi dari internet untuk memperkaya media pembelajaran yang digunakan dalam pembelajaran. Survei tersebut juga menunjukkan bahwa guru hampir tidak pernah mengikuti atau dilibatkan dalam kegiatan pelatihan-pelatihan atau lokakarya tertentu oleh pihak atau instansi yang berkepentingan untuk mengembangkan kemampuan guru dalam mendesain media pembelajaran sendiri. Fakta-fakta inilah yang setidaknya merupakan pemicu utama pembelajaran konstrukvistik pada era kurikulum 2013 di SD yang bersifat tematik terpadu belum direalisasikan dengan baik, sehingga pembelajaran terkesan konvensional (Leasa, Batlolona, Enriquez, \& Kurnaz, 2018; Rifayanti, 2017). Fakta tersebut bukan hanya dijumpai pada pembelajaran di sekolah, namun juga di kampus bagi mahasiswa calon guru SD (Irfan, 2012).

Fakta lainnya menunjukkan bahwa 90\% guru belum pernah menggunakan aplikasi atau software apapun untuk mendesain multimedia pembelajaran berupa video atau animasi pembelajaran. Hal ini disebabkan karena guru merasa cukup dengan menggunakan media yang sudah ada, atau belum memiliki kebutuhan yang mendesak akan pentingnya menggunakan media pembelajaran lain misalnya dalam tampilan berupa multimedia seperti video atau animasi. Sebanyak $10 \%$ guru yang juga berperan sebagai operator di sekolah memiliki kemampuan dalam membuat media pembelajaran, misalnya dengan mengedit kembali video dari youtube atau menggunakan aplikasi dari android. Penulisan artikel ini bertujuan untuk mengembangkan kompetensi guru SD dalam mendesain video pembelajaran dengan menggunakan aplikasi sparkol videoscribe.

\section{METODE KEGIATAN}

Mitra yang terlibat dalam kegiatan pengembangan video scribe adalah KKG Gugus 1 Kecamatan Saparua Kabupaten Maluku Tengah. Ada 8 SD yang terlibat dalam kegiatan ini, di mana pada setiap sekolah mengutus 4-5 guru termasuk para kepala sekolah. Khusus untuk pelatihan menyangkut pembuatan video pembelajaran dengan menggunakan aplikasi sparkol videoscribe dilaksanakan dalam 2 hari yakni tanggal 19 dan 20 Agustus 2019. Pembuatan video pembelajaran tersebut didahului dengan pelatihan desain perangkat pembelajaran berbasis HOTS.

Metode yang digunakan dalam kegiatan pengabdian ini adalah ceramah dan workshop. Ceramah berupa penyampaian informasi tentang media pembelajaran dalam perangkat pembelajaran serta manfaatnya, macam-macam media pembelajaran, media pembelajaran berbasis sparkol videoscribe. Materi yang disampaikan dalam workshop adalah pembuatan video pembelajaran menggunakan aplikasi sparkol videoscribe, termasuk pengenalan fitur-fitur Video Scribe serta pemanfaatannya.

Video pembelajaran yang dihasilkan dalam kegiatan PkM ini selanjutnya divalidasi oleh ahli media pembelajaran untuk memperoleh masukan dan saran perbaikan. Selanjutnya akan direvisi sesuai saran perbaikan tersebut, hingga layak digunakan dalam kegiatan pembelajaran. Validator yang dilibatkan antara lain: Dr. Th. Souisa, M.Pd (ahli teknologi pembelajaran dari Universitas Pattimura) dan Muh. Sayyadi, S.Pd., M.Pd (ahli media pembelajaran dari Universitas Kanjuruhan Malang). 


\section{HASIL \& PEMBAHASAN}

Program kemitraan Masyarakat ini dilaksanakan untuk meningkatkan kompetensi guru dalam mendesain serta mengembangkan multimedia pembelajaran berupa video pembelajaran dengan menggunakan software VideoScribe, termasuk mengembangkan kompetensi ICT bagi mitra. Program tersebut dilaksanakan melalui kegiatan pelatihan atau workshop pada KKG gugus 1 Kecamatan Saparua Kabupaten Maluku Tengah. Kegiatan pelatihan didahului oleh ceramah atau penyampaian informasi oleh narasumber terkait dengan desain perangkat pembelajaran SD khususnya Rencana Pelaksanaan Pembelajaran tematik terpadu, termasuk di dalamnya ada komponen media pembelajaran yang merupakan fokus dari kegiatan ini. Materi tentang desain perangkat pembelajaran dinilai penting untuk disampaikan supaya mitra memiliki wawasan yang komprehensif dalam mendesain perangkat pembelajaran, serta fungsi dan bentuk-bentuk media pembelajaran. Media pembelajaran yang baik tanpa diikuti oleh desain kegiatan pembelajaran yang relevan serta mengacu pada strategi atau model pembelajaran tertentu tampaknya hanya sebagai penghias kegiatan pembelajaran. Padahal model pembelajaran menjadi kerangka kegiatan pembelajaran, yang didukung oleh media pembelajaran untuk kemudaha penyampaian informasi pembelajaran kepada pebelajar.

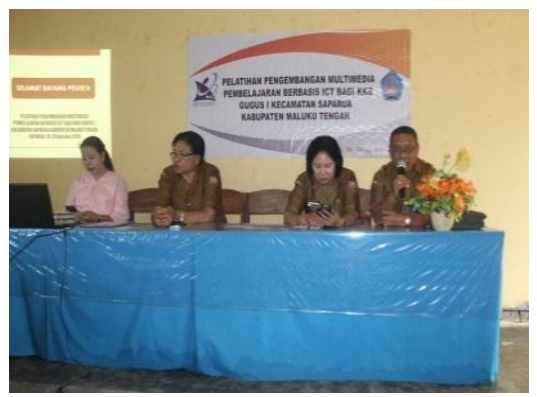

Gambar 1. Kegiatan pembukaan pelatihan

Sesi selanjutnya adalah ceramah kepada mitra untuk memperkenalkan media pembelajaran, khususnya yang berbentuk multimedia. Multimedia pembelajaran yang diperkenalkan berupa video yang didesain menggunakan software Sparkol VideoScribe. Instalasi software tersebut dilakukan kepada seluruh peserta, sebelum dijelaskan fitur-fitur yang terdapat di dalamnya. Kegiatan pelatihan dilakukan untuk membuat video pembelajaran dengan menggunakan software tersebut, di mana mitra diatur dalam bentuk small group berdasarkan asal sekolah. Hal ini dilakukan supaya peserta dapat bekerja kooperatif untuk saling melengkapi dalam rangka menghasilkan produk yang diharapkan. Proses pembuatan video tersebut tidak mudah, dengan demikian maka setiap kelompok perlu mengelola kelompoknya dalam berbagi peran sehingga semua peserta difungsikan untuk membuat salah satu produk. Di akhir kegiatan pelatihan diberikan kesempatan kepada peserta untuk mempresentasikan hasil kerja. Hasil kerja dikomentari oleh pemateri untuk direvisi. Selanjutnya, peserta ditugaskan untuk melakukan revisi atau merancang kembali video pembelajaran yang baru untuk diserahkan kepada tim untuk divalidasi oleh ahli media sebelum digunakan.

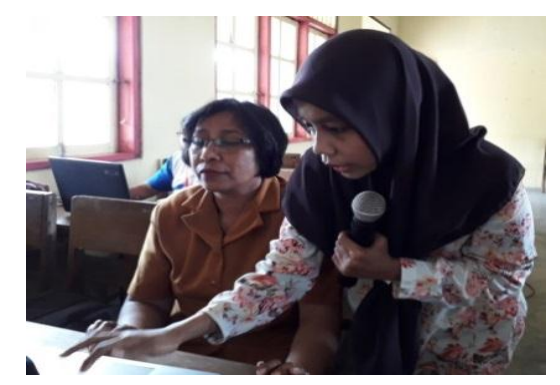

Gambar 2. Pendampingan pembuatan video pembelajaran

Di akhir kegiatan pelatihan diberikan post test kepada peserta untuk mengetahui tingkat penguasaan terhadap materi pelatihan yang diberikan, terutama yang berkaitan dengan desain perangkat pembelajaran dan video pembelajaran. Dari hasil post test diperoleh informasi bahwa $85 \%$ guru sudah dapat mengembangkan RPP secara mandiri, tanpa sepenuhnya mengikuti buku guru, serta mampu merumuskan indikator pencapaian kompetensi dan tujuan pembelajaran secara benar. Sebanyak $75 \%$ guru sudah dapat membedakan penggunaan model dan metode pembelajaran, serta mendesain kegiatan pembelajaran berdasarkan sintaks model pembelajaran secara benar. Terkait dengan media pembelajaran, diperoleh informasi bahwa 70\% guru telah mengembangkan media pembelajaran sendiri termasuk yang berupa multimedia berupa dengan menggunakan sparkol videoscribe dengan baik. Hal ini mengindikasikan bahwa mitra secara mandiri sudah mengalami peningkatan kompetensi pedagogis dalam mendesain perangkat dan media pembelajaran dibandingkan dengan keadaan terdahulu sebelum dilakukan kegiatan PKM. 
Kegiatan PKM berupa pelatihan yang dilakukan oleh tim untuk menunjukkan adanya kolaborasi antara pihak universitas dan masyarakat untuk meningkatkan kualitas pendidikan khususnya pada level pendidikan dasar. Sebagai sektor terkemuka dalam pendidikan, universitas tidak hanya memiliki sumber daya yang ada berguna untuk mendukung pengembangan pendidikan tetapi mereka juga memiliki tanggung jawab untuk meningkatkan kualitas sumber daya manusia, termasuk kompetensi guru di sekolah (Situmorang, Gultom, Hamid K, Panjaitan, \& Ritonga, 2018).

Peningkatan kompetensi guru mitra berdasarkan hasil post test tersebut menginformasikan bahwa guru masa kini membutuhkan berbagai keterampilan yang membangun satu sama lain, keterampilan itu terdiri dari keahlian teknis dan keahlian pedagogis untuk menggunakan ICT. Kedua hal tersebut sangat diperlukan untuk mengoperasikan komputer termasuk softwaresoftware yang diperlukan dalam mendesain suatu produk pembelajaran tertentu, misalnya multimedia. Dengan demikian pemanfaatan ICT pada lingkungan belajar tertentu yang diintegrasikan ke dalam pembelajaran mampu meningkatkan efektivitas iklim dan proses pembelajaran di institusi pendidikan (Hampel, 2009).

Produk pelatihan berupa berupa video pembelajaran yang didesain oleh mitra dikumpulkan untuk diberikan kepada validator yakni ahli teknolog dan ahli media pembelajaran untuk divalidasi. Indikator produk yang dinilai antara lain: kualitas tampilan, aspek kebahasaan, aspek keterlaksanaan, dan aspek kemudahan penggunaan. Tujuan validasi produk ini adalah untuk mendapatkan penilaian terhadap kelayakan produk yang dikembangkan, sehingga akan difollow up melalui revisi produk hingga produk layak digunakan. Hasil validasi yang dilakukan oleh kedua ahli ditampilkan pada Tabel 1.

Tabel 1. Hasil Penilaian Ahli Desain Media Sparkol Videoscribe

\begin{tabular}{|c|c|c|c|c|c|c|}
\hline No & Pernyataan & $\begin{array}{c}\text { Skor } \\
\text { Validator 1 }\end{array}$ & $\begin{array}{c}\text { Skor } \\
\text { Validator } 2 \\
\end{array}$ & $\begin{array}{c}\text { Rerata } \\
\text { Skor }\end{array}$ & $\begin{array}{c}\text { Kriteria } \\
\text { Kevalidan }\end{array}$ & Ket \\
\hline 1 & Kualitas gambar & 80 & 100 & 90 & Sangat valid & Tidak revisi \\
\hline 2 & Ukuran huruf/ teks & 80 & 80 & 80 & Sangat valid & Tidak revisi \\
\hline 3 & $\begin{array}{l}\text { Warna dan jenis } \\
\text { huruf }\end{array}$ & 80 & 60 & 70 & Cukup valid & Tidak revisi \\
\hline 4 & $\begin{array}{l}\text { Gambar dan video } \\
\text { yang ada } \\
\text { menyampaikan } \\
\text { konsep kompleks }\end{array}$ & & & & & \\
\hline & $\begin{array}{l}\text { secara visual dan } \\
\text { dinamis, serta } \\
\text { kejelasan gambar } \\
\text { menjelaskan konsep } \\
\text { materi }\end{array}$ & 60 & 80 & 70 & Cukup valid & Tidak revisi \\
\hline 5 & $\begin{array}{l}\text { Tampilan video } \\
\text { menarik }\end{array}$ & 80 & 80 & 80 & Sangat valid & Tidak revisi \\
\hline 6 & $\begin{array}{l}\text { Kreatif dalam } \\
\text { penuangan ide/ } \\
\text { gagasan }\end{array}$ & 80 & 80 & 80 & Sangat valid & Tidak revisi \\
\hline 7 & $\begin{array}{l}\text { Penggunaan bahasa } \\
\text { yang komunikatif } \\
\text { dan mudah dipahami }\end{array}$ & 100 & 100 & 100 & Sangat valid & Tidak revisi \\
\hline 8 & $\begin{array}{l}\text { Kesesuaian } \\
\text { penggunaan dengan } \\
\text { tingkat } \\
\text { perkembangan siswa }\end{array}$ & 100 & 80 & 90 & Sangat valid & Tidak revisi \\
\hline 9 & $\begin{array}{l}\text { Penggunaan bahasa } \\
\text { tidak menimbulkan } \\
\text { penafsiran ganda }\end{array}$ & 100 & 80 & 90 & Sangat valid & Tidak revisi \\
\hline 10 & $\begin{array}{l}\text { Dapat digunakan } \\
\text { secara klasikal/ } \\
\text { individual }\end{array}$ & 100 & 80 & 90 & Sangat Valid & Tidak revisi \\
\hline 11 & $\begin{array}{l}\text { Fleksibilitas } \\
\text { penggunaannya }\end{array}$ & 100 & 80 & 90 & Sangat valid & Tidak revisi \\
\hline
\end{tabular}




\begin{tabular}{|c|c|c|c|c|c|c|}
\hline No & Pernyataan & $\begin{array}{c}\text { Skor } \\
\text { Validator 1 }\end{array}$ & $\begin{array}{c}\text { Skor } \\
\text { Validator } 2\end{array}$ & $\begin{array}{c}\text { Rerata } \\
\text { Skor }\end{array}$ & $\begin{array}{c}\text { Kriteria } \\
\text { Kevalidan }\end{array}$ & Ket \\
\hline 12 & $\begin{array}{l}\text { Penyajian materi } \\
\text { memungkinkan } \\
\text { siswa untuk belajar } \\
\text { mandiri }\end{array}$ & 80 & 100 & 90 & Sangat valid & Tidak revisi \\
\hline 13 & $\begin{array}{l}\text { Kemudahan } \\
\text { menggunakan video }\end{array}$ & 100 & 100 & 90 & Sangat valid & Tidak revisi \\
\hline 14 & $\begin{array}{l}\text { Kepraktisan dalam } \\
\text { menggunakan video }\end{array}$ & 100 & 100 & 90 & Sangat valid & Tidak revisi \\
\hline & Jumlah & 1240 & 1200 & 1220 & & \\
\hline & Rerata & 88.57 & 85.71 & 87.14 & Sangat valid & Tidak revisi \\
\hline
\end{tabular}
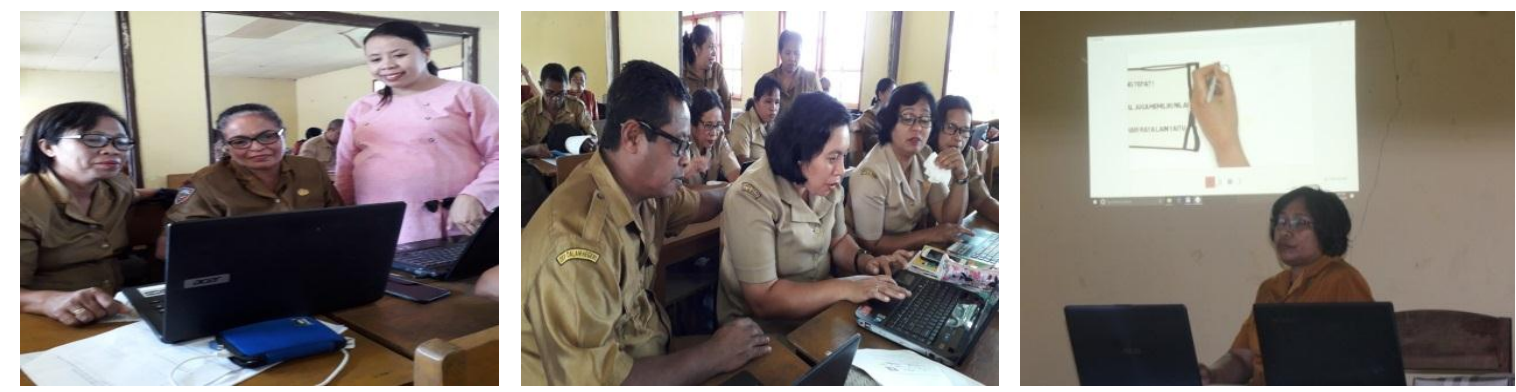

Gambar 3. Proses pembuatan video pembelajaran dalam small group dan presentasi produk berupa video pembelajaran tematik oleh peserta

Catatan kualitatif terkait dengan hasil validasi yang disampaikan oleh Validator 1 antara lain: Gambar harus diperbesar sedikit, 2) ukuran hurufnya juga diperbesar, 3) temanya Temanya berbagai pekerjaan, tetapi dijelaskan hanya 1 pekerjaan. Bisa dijelaskan beberapa jenis pekerjaan. Kecuali dari awal sudah di kasih tahu jenis jenis pekerjaan khususnya pekerjaan di laut apa saja. Selain itu, Validator 1 juga memberikan komentar terhadap produk yang dikembangkan. Komentar Validator 1 tersebut perlu untuk diperhatikan. Komentar itu antara lain: 1) gerakan tulisannya terlalu cepat, sehingga ada beberapa kalimat panjang yang belum selesai dibaca tapi sudah terganti, 2) Siswa SD kelas 4 belum tahu apa itu diagram Venn. Padahal dalam video langsung saja ditulis perbedaan nelayan tradisional dan modern, persamaannya nelayan tradisional dengan modern, 3) kalau bisa pada waktu tayangan yang menampilkan pertanyaan durasinya dilamakan sedikit, supaya anak bisa membaca dulu pertanyaannya dengan baik. Kesimpulan hasil validasi oleh Validator 1 menyatakan bahwa video pembelajaran tersebut layak digunakan dengan sedikit revisi. Validator 2 memberikan komentar bahwa perlu adanya penyesuaian antara warna huruf dan jenis huruf dengan warna backgroud. Kesimpulan dari hasil validasi produk oleh validator 2 adalah produk layak digunakan tanpa revisi. Catatan kualitatif dan komentar kedua validator tetap digunakan sebagai bahan perbaikan produk sebagaimana ditunjukkan pada Gambar 4 - Gambar 6. Dengan demikian, produk tersebut kembali diperbaiki sebelum digunakan dalam uji coba skala kecil maupun besar, serta disebarluaskan kepada pihak-pihak yang berkepentingan.
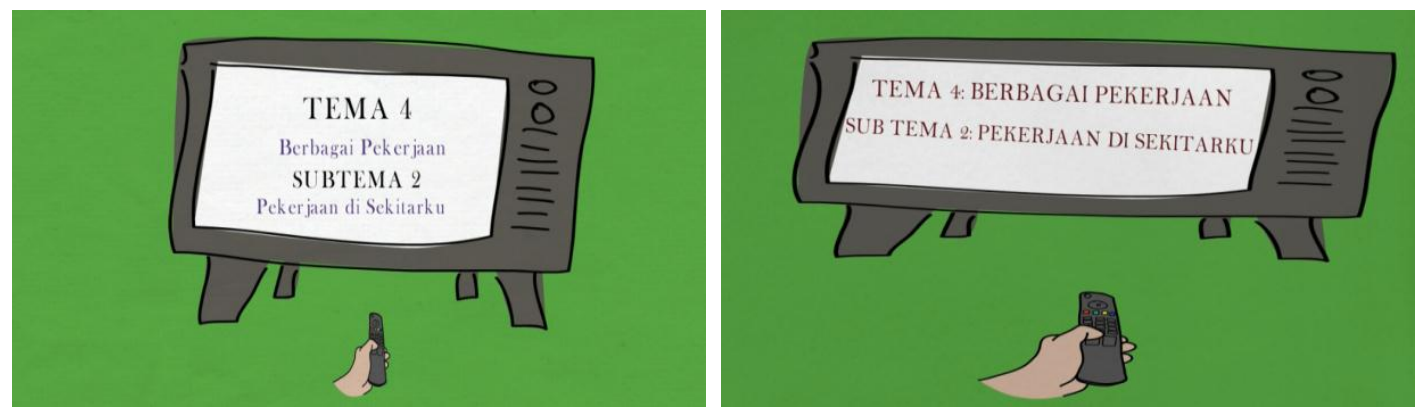

Gambar 4. Tampilan video sebelum dan sesudah validasi terkait catatan kualitatif validator tentang ukuran dan jenis huruf 

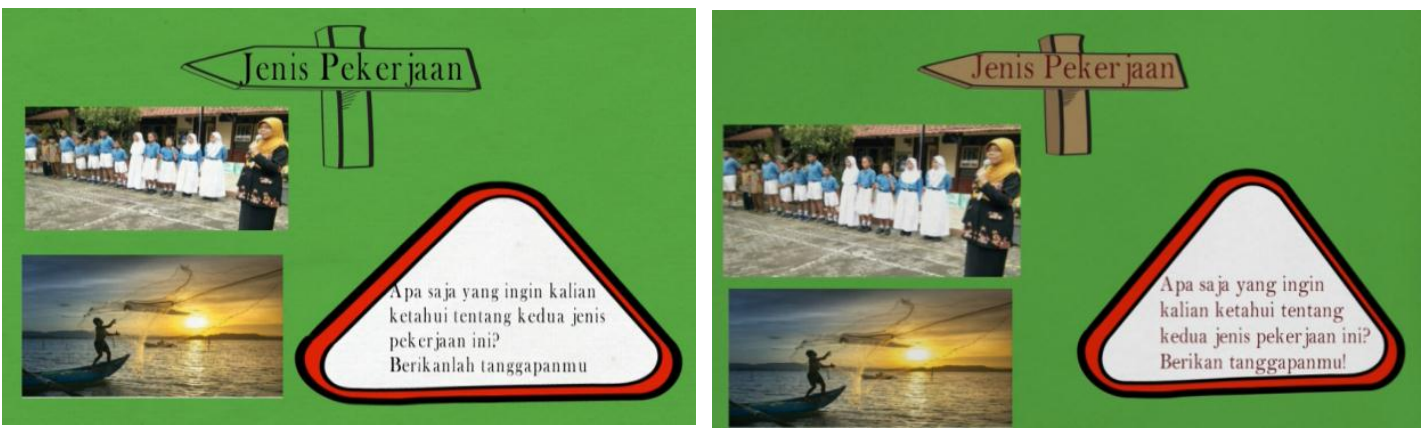

Gambar 5. Tampilan video sebelum dan sesudah validasi terkait catatan kualitatif validator tentang penyesuaian antara warna huruf, jenis huruf dengan warna backgroud
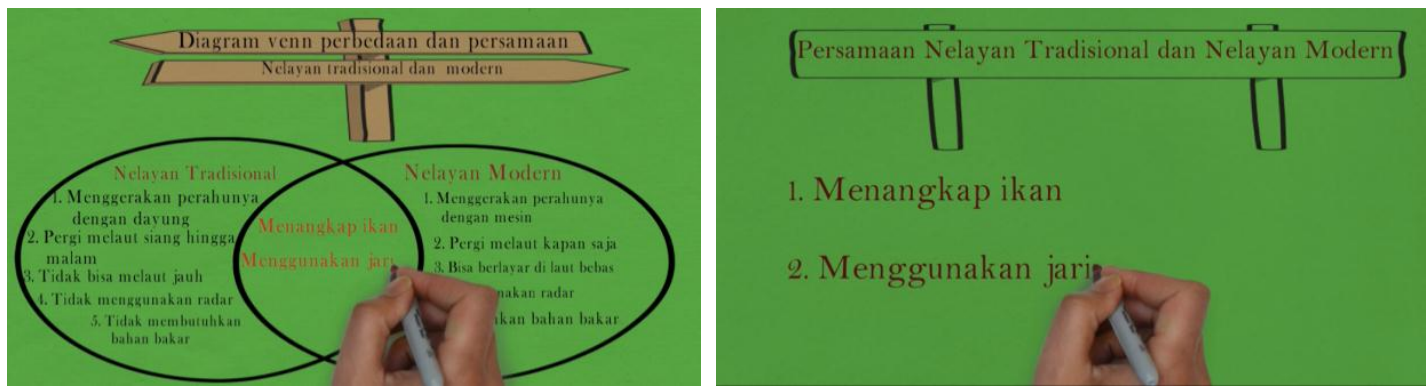

Gambar 6. Tampilan video sebelum dan sesudah validasi terkait komentar validator bahwa tidak perlu digunakan kata diagram Venn dalam video

\section{KESIMPULAN \& SARAN}

Program Kemitraan Masyarakat yang dilakukan kepada mitra berupa pelatihan pengembangan video pembelajaran dinilai bermanfaat karena meningkatkan kompetensi profesional mitra dalam hal desain perangkat pembelajaran yang di dalamnya telah mencakup desain media pembelajaran. Dalam hal ini media pembelajaran yang dikembangkan adalah video pembelajaran dengan menggunakan sparkol videoscribe. Namun demikian, peningkatan kemampuan mitra khususnya dalam mendesain atau membuat media pembelajaran semacam ini perlu diperdalam dan diperkaya lagi dengan berbagai contoh-contoh yang lain. Sebagaimana terlihat bahwa dari hasil posttes, kemampuan mitra untuk mengembangkan kemampuan tersebut telah mencapai $65 \%$ atau meningkat $45 \%$ setelah diberikan pelatihan. Kegiatan pendampingan dari Tim masih sangat diperlukan oleh peserta untuk memperkuat pemahaman, serta mendorong kreativitas mitra dalam mendesain produk-produk yang baru. Hal ini bertujuan untuk mengembangkan literasi ICT di kalangan mitra, sehingga menjadi pembelajar yang unggul.

\section{UCAPAN TERIMA KASIH}

Terima kepada DRPM Kemenristekdikti yang telah membiayai program pengabdian kepada masyarakat (PPM) melalui skim hibah program kemitraan masyarakat (PKM) tahun 2019.

\section{DAFTAR PUSTAKA}

Drent, M., \& Meelissen, M. (2008). Which factors obstruct or stimulate teacher educators to use ICT innovatively? Computers and Education, 51(1), 187199.

https://doi.org/10.1016/j.compedu.2007.0 5.001

Ellis, R., \& Childs, M. (1999). The effectiveness of video as a learning tool in on- line multimedia modules. Journal of Educational Media, 24(3), 217-223. https://doi.org/10.1080/13581659902403 05

Hampel, R. (2009). Training teachers for the multimedia age: Developing teacher expertise to enhance online learner interaction and collaboration. Innovation in Language Learning and Teaching, 3(1), 35-50. https://doi.org/10.1080/17501220802655 425

Hasse, C. (2017). Technological literacy for teachers. Oxford Review of Education, 43(3), 365-378. https://doi.org/10.1080/03054985.2017.1 305057

Irfan, M. 2012. Pengembangan multimedia interaktif untuk pembelajaran mata kuliah 
konsep dasar IPA I. Jurnal Publikasi, 2(1), 7-15.

Leasa, M., Batlolona, J. R., Enriquez, J. J., \& Kurnaz, M. A. (2018). Determination Of elementary students' learning styles reviewed from gender aspects. Journal of Education and Learning (EduLearn), 12(3), 478. https://doi.org/10.11591/edulearn.v12i3.8 978

Mishra, P., \& Mehta, R. (2017). What we educators get wrong about 21st-century learning: results of a survey. Journal of Digital Learning in Teacher Education, 33(1), 6-19. https://doi.org/10.1080/21532974.2016.1 242392

Mitra, B., Lewin-Jones, J., Barrett, H., \& Williamson, S. (2010). The use of video to enable deep learning. Research in Post-Compulsory Education, 15(4), 405414.

https://doi.org/10.1080/13596748.2010.5 26802

Orlando, J. (2013). ICT-mediated practice and constructivist practices: Is this still the best plan for teachers' uses of ICT? Technology, Pedagogy and Education, 22(2),

231-246. https://doi.org/10.1080/1475939X.2013.7 82702

Rifayanti, Z. E. T. 2017. Pengembangan Multimedia IPA Dengan Model Quantum Teaching Di SD Kecamatan Lakarsantri Surabaya. Jurnal Publikasi Pendidikan, 7(1), 1-5.

Situmorang, M., Gultom, S., Hamid K, A., Panjaitan, A. M., \& Ritonga, W. (2018). University-government collaboration model to improve school teacher competence in North Sumatra, Indonesia. International Journal of Training Research, 16(3), 249-266. https://doi.org/10.1080/14480220.2018.1 576324

Tawarah, H. M. (2017). The degree to which teachers practicing teaching in Shobak university college by using creative thinking skills as perceived by students. Journal of Social Sciences, 51(1-3), 1722. https://doi.org/10.1080/09718923.2017.1 305578

Voogt, J., \& Roblin, N. P. (2012). A comparative analysis of international frameworks for 21 st century competences: Implications for national curriculum policies. Journal of Curriculum Studies, 44(3), 299-321. https://doi.org/10.1080/00220272.2012.6 68938 